\title{
THE LIGHT JUDGMENT DECISION IN THE CASE OF CORRUPTION: THE IMPLICATIONS FOR THE SENSE OF PUBLIC JUSTICE
}

\author{
OksidelfaYanto \\ Pamulang University \\ Email: dosen00240@unpam.ac.id \\ Yoyon M Darusman \\ Pamulang University \\ Email: dosen00040@unpam.ac.id \\ Ichwani Siti Utami \\ Pamulang University \\ Email: dosen00655@unpam.ac.id \\ Nurdiyana \\ Pamulang University \\ Email: dosen02080@unpam.ac.id
}

\begin{abstract}
This research purposes to recognize the crime of corruption that occurs can injure the justice of society, then also want to know the lightness of the judge's decision in corruption and its implications for a sense of justice. The research method that I use in this paper is a normative juridical research method by multiplying data sources through documentation research on secondary data. The results of the study show that corruption can harm the justice of society, this is because the perpetrators of corruption have taken people's rights against the law, the perpetrators of corruption hamper the progress of the nation, corruptors corrupt democracy and afflict the people. The lightness of judges' decisions in corruption cases has implications for people's sense of justice. This is because the judge's decision is the crown and the culmination of the reflection of the values of justice, essential truth and human rights. The judge is the spearhead of justice for society.
\end{abstract}

Keywords: Judges, decisions, corruption, justice.

\section{INTRODUCTION}

If we look back on the history of Indonesian politics, the demand for eradicating corruption has been held up since the days of President Soeharto. The end of President Soeharto's rule was ended by student action. Students and some national figures demanded President Soeharto step down from his position as ruler of the new order. One of these demands is to eradicate the culture of corruption, collusion and nepotism that occurred throughout his administration, in addition to other demands. The demands launched by the student elements and some of these figures indicate that the disease of corruption cannot be allowed to live and develop in the motherland. But the reform agenda which ultimately forced President Soeharto down from his position and gave birth to 
new leaders, has not succeeded in maximally eradicating corrupt behavior in the life of the nation and state.

Just look, the government has come and gone, but the disease of corruption in Indonesia to this day still leaves a never-ending story. The Indonesian state is still shrouded in a dark cloud of corruption with an increasingly structured and systematic mode. Laws are made with the intention to eradicate corruption. Indonesia has Law Number 31 of 1999 concerning Eradication of Corruption Crimes and then Law Number 20 of 2001 concerning Amendments to Law Number 31 of 1999 concerning Eradication of Corruption Crimes.

Along with the development of legislation to eradicate corruption, certain institutions or bodies have been formed, both of which specifically deal with the eradication. Thus, the establishment of the law was also followed by the establishment of anti-corruption bodies and commissions. As a result, instead of corruption reduced, even more rampant. Both in the executive, judicial and legislative branches. ${ }^{1}$

Corruption that occurs in the executive, legislative, and judiciary, is known as widespread bureaucratic corruption, namely corruption committed by people who are holding state institutional power. ${ }^{2}$ According to Harkristuti Harkrisnowo, the perpetrators of corruption are not people carelessly because they have access to corruption, by abusing their authority, opportunities or means. ${ }^{3}$

From what was described above, the birth of a new law to eradicate corruption crimes is certainly a breath of fresh air in creating a country free from corrupt behavior. The spirit and spirit of reform that were considered as the spirit of the formation of the new law was believed to be giving birth to a new breakthrough, especially with the mandate to establish a commission to eradicate corruption as a new instrument to eradicate corruption. This means that the birth of Law Number 30 of 2002 is a mandate. The KPK is expected to be the main institution that partners with the Police and Prosecutors in eradicating corruption.

Law Number 20 of 2001 is a law that was born solely to correct weaknesses and shortcomings of Law Number 31 of 1999. Some of these weaknesses were later revised in the new law. The revisions to the weaknesses of Law No. 31 of 1999 are: First, the withdrawal of certain acts of articles of the Criminal Code as criminal acts of corruption is carried out by adopting the contents of the article as a whole so that the changes to the Criminal Code will not result in unsynchronized. Second, the regulation of the reasons for the imposition of capital punishment is based on acts of corruption committed on funds used for overcoming certain conditions such as dangerous conditions, national disasters, and the monetary crisis. Third, the enactment of a transitional regulation that expressly becomes a bridge between the old law, which is not valid with the new law, so that it no longer raises the risk of a legal vacuum that can harm the eradication of criminal acts of corruption.

Baharuddin Lopa and Andi Hamzah said that in terms of legal material, the provisions on eradicating corruption in Indonesia have been quite complicated, maybe even excessive. However, these provisions are not just as literary works. ${ }^{4}$ The existing

\footnotetext{
${ }^{1}$ H. Elwi Danil, 2011, Korupsi: Konsep, Tindak Pidana, Dan Pemberantasannya, Raja Grafindo Persada, Jakarta, P. 65.

${ }^{2}$ Amir Syamsuddin, 2008, Integritas Penegak Hukum, Hakim, Jaksa, Polisi, Dan Pengacara, Gramedia, Jakarta, P. 135.

${ }^{3}$ Harkristuti Harkrisnowo, "Korupsi, Konspirasi dan Keadilan di Indonesia", Jurnal Dictum LeIP, Edisi I, Jakarta, Lentera Hati, 2002, P. 67.

${ }^{4}$ Syaiful Bakhri, 2009, Pidana Denda Dan Korupsi, Total Media, Yogyakarta, P. 386.
}

2 Jurnal IUS Kajian Hukum dan Keadilan 
legal provisions should be used as a guideline to take action against corruptors. It is not possible to eradicate corruption by promoting mere theory.

In understanding the study of criminal acts of corruption, in addition to the theoretical aspect, it is also treated as a juridical understanding or the basis of legal provisions. This is because, in every act of eradication of corruptors and corrupt practices, there must be a principle or legal basis is one of the principles of criminal law, where punishment cannot be imposed on a criminal act committed by someone without the rules governing it.

Without the law to eradicate corruption and the existence of institutions or agencies to eradicate corruption, corruption continues. The culprit comes one after another. Not yet finished a corruption case was tried and decided by the court, another corruption case appeared again. Those in power, such as Governors, Regents, Mayors and even to Ministerial levels, are also involved in corruption.

Corrupt power is clearly an indication, how political greed is still a mental illness that continues to greet the dark stage of our political world. This, among other things, arises as a result of the perception of the community itself which is often excessive and sarcastic in interpreting the meaning of a power. Power, for example likened to a spring that can irrigate dry fields in the midst of a long dry storm for hundreds of years, people's imagination about a power is generally identical to that reflected in the stories of the royal palace-throne full of sparkling pieces gold and diamond pieces. In a palace, it is imagined a form of peace, coolness and peace. ${ }^{5}$

Corruption is an extraordinary crime, so that according to the provisions of Article 15 of Law Number 31 of 1999 in conjunction with Law Number 20 of 2001, corruptors can be given severe criminal sanctions the case to the perpetrators of corruption trials. Normatively, this is a special rule in the Act on corruption without any exception. In Article 15 of Law Number 31 of 1999 jo Law Number 20 of 2001 contains various criminal threats for perpetrators of corruption. The threat starts from the mild with a fine to the weight of death penalty. ${ }^{6}$

As an extraordinary category of crimes, corruptors must be stopped from taking public money. The corruptors have damaged the country's economy, from that must be eradicated in extraordinary ways, one of these ways is by establishing a state institution called the Corruption Eradication Commission (KPK) based on Law Number 30 of 2002. As well as giving the death penalty threat to perpetrators of corruption. In dealing with corruption issues by the KPK, a Corruption Court (Tipikor) was formed.

One of the characteristics of the Corruption Court (Tipikor) that distinguishes it from the district court in examining corruption cases is the composition of judges. At the beginning of the establishment of the Corruption Court, it was regulated in Article 56 paragraph (1) of Law Number 30 of 2002 concerning the Corruption Eradication Commission regarding judges examining corruption cases in the Corruption Court consisting of District Court judges, often referred to as Career and Judge judges.

The definition of Career Judges in the Corruption Court Law, regulated in Article 1 number (2) of Law Number 46 of 2009 concerning the Corruption Court, states that

\footnotetext{
${ }^{5}$ M. Dede Ridwan Dan M. Muhadjirin, 2003, Membangun Konsensus Pemikiran Dan Praktik Politik Akbar Tanjung, Pustaka Sinar Harapan, Jakarta, P. 13.

${ }^{6}$ Endang Jumali, 2016, Rekonstruksi Sanksi Hukum Pidana Korupsi Di Indonesia, Kritik Nazharyyah Al-Ta'zir, Terhadap Undang-Undang Nomor 20 Tahun 2001 Tentang Pemberantasan Tindak Pidana Korupsi, PT. Saadah Pustaka Mandiri, Jakarta, P. 49.
} 
career judges are judges at the District Court, High Court and Supreme Court who are appointed as corruption judges. Ad hoc Judges (Non-career) judges are explained in Article 1 number (6) of Law Number 46 of 2009 concerning the Corruption Court. Ad hoc judges (Non-career) are judges who are temporarily assigned to have expertise and experience in certain fields to examine, hear and decide on a case whose appointment is regulated by law.

To ward off corruption crime as a crime that is dangerous for social life, a culture change is needed, however, cultural change is a very big change and not an easy job, even according to these changes requires careful study and writing.

This paper then tries to look at the problem of corruption in the perspective of a sense of community justice. Besides that, it is also in the perspective of judges' decisions for perpetrators of corruption. In a variety of judges' decisions, the number of corruption defendants was severed free or out of law. If there are those convicted, the sentence is very light and hurts the sense of justice of the community. ${ }^{7}$

The decision of a fair judge will at least affect the sense of justice of the community. From that the fairest decision is the hope of all elements of society against the perpetrators of corruption by the judge. In the end this article clearly will not be able to answer the problem of corruption that exists. However, this paper is only as a suggestion for the phenomenon of corruption cases in the realm of criminal law which can be used as a reference in the development of the science of criminal law, especially with regard to the issue of corruption.

Based on the description above, then in this writing the author can formulate the problem as follows:

1. Does the culture of corruption that occurs can hurt the sense of justice of society?

2. What are the implications for a sense of community justice for the lightness of a judge's decision in a criminal act of corruption?

The type of research that I use is normative legal research, with the data collection method used is library research. The data used includes primary legal material (binding materials), secondary legal material (legal material that provides an explanation of primary legal material). ${ }^{8}$ To achieve the research objectives, the approach in this study is carried out carefully through the provisions of legislation and various doctrines (opinions of legal experts) relating to the problem of corruption. The materials that have been collected are then analyzed by analytical descriptive method, so that the picture is related to the existing problems.

\section{DISCUSSION}

\section{Culture of Corruption and a Sense of Community Legal Justice}

The most important impact of corruption is the collapse of morality, morality, integrity and national religiosity. Corruption abandons the exemplary nature of leaders or bureaucrats who should be shown to the people. Corruption also fosters greed, possesses dishonesty, cunning, mental thieves and lazy culture. The diversity of this nation also collapsed by corruption. ${ }^{9}$

\footnotetext{
${ }^{7}$ Satjipto Rahardjo, 2009, Hukum Progresif, Sebuah Sintesa Hukum Indonesia, Genta Publishing, Yogyakarta, p. 46.

${ }^{8}$ Soerjono Soekanto dan Sri Mamudji, 2001, Penelitian Hukum Normatif, Raja Grafindo, Jakarta, p."

${ }^{9}$ Alfitra, 2014, Modus Operandi Pidana Khusus Diluar KUHP, Raih Asa Sukses, Depok, P. 37-38.
} 
In its history, corruption as a crime committed by the perpetrators is not a new problem in Indonesia. Corruption has been crisscrossing people's lives. Many laws and regulations have been made. But corruption has never been lost or even reduced from this country. The corruptors continue to carry out the action. The state seems helpless to block it. Then what is meant by corruption?

According to A. Hamzah, the definition of corruption is interpreted literally, namely; decay, ugliness, depravity, dishonesty, can be bribed, immoral, deviations from chastity, insulting words or slanderous words. ${ }^{10}$ While in the Big Indonesian Dictionary (Kamus Besar Bahasa Indonesia), corruption literally means: bad, damage, likes to use goods (money) entrusted to him, can be bribed (through his power for personal gain). The meaning of the terminology, corruption is fraud or embezzlement (state or company money) for personal or other people's interests. ${ }^{11}$

The formal juridical definition of corruption in Indonesia is stipulated in the law on combating corruption. Law Number 31 of 1999 in conjunction with Law Number 20 of 2001 states that corruption in terms of terminology is against the law of committing acts to enrich oneself or other people or a corporation that can harm the state's finance or the country's economy. There are 13 pieces in Article No. 31 of 1999 which was amended by Act No. 20 of 2001 concerning the Eradication of Corruption Crimes. Based on these articles, corruption is formulated into 30 forms / types of corruption. These articles explain in detail about acts that can be subject to criminal sanctions for corruption. The thirty forms / types of corruption can basically be grouped as follows: 1 . State financial losses 2. Bribery 3.Darkening in positions 4.Extortion 5.Cheating actions 6.Conflict of interest in procurement 7 .Gratification. ${ }^{12}$

The word corruption has been widely known by the public, but its definition has not yet been completely recorded. The definition of corruption evolved in every era, civilization, and territorial. The formulation can be different depending on the pressure point and approach, both from a political, sociological, economic and legal perspective. Corruption as a phenomenon of irregularities in social, cultural, social and state life has been studied and studied critically by many scientists and philosophers. Aristotle, for example, who was followed by Machiavelli, has formulated something he calls moral corruption. ${ }^{13}$

From the description of the definition of corruption above, then as stated in Article 2 of Law Number 31 Year 1999 in conjunction with Law Number 20 Year 2001 concerning Eradication of Corruption Crime, there are several important elements, namely: (1) Everyone; (2) Fighting the Law; (3) Enrich themselves / others / corporations; (4) Can be detrimental to the State's or the country's economy.

Corruption is a criminal act that has a large contribution to the obstruction of achieving the goals of the state, so that making all the resources owned by Indonesia is not directly proportional to the fate of society. In connection with this, one way for

\footnotetext{
${ }^{10}$ A.Hamzah, 2005, Pemberantasan Korupsi Melalui HukumPidana Nasional Dan Internasional, Raja Grafindo Persada, Jakarta, p. 4-5.

${ }^{11}$ Departemen Pendidikan dan Kebudayaan RI, KamusBesar Bahasa Indonesia, 1995, BalaiPustaka, Jakarta, p. 527.

${ }^{12}$ M. SyamsaArdisasmita, 2006, Definisi Korupsi Menurut Perspektif Hukum Dan E-Announcement Untuk Tata Kelola Pemerintahan Yang Lebih Terbuka, Transparan Dan Akuntabel, Disampaikan Dalam Seminar Nasional Upaya Perbaikan Sistem Penyelenggaraan Pengadaan Barang/Jasa Pemerintah Jakarta, 23 Agustus.

${ }^{13}$ Albert Hasibuan, 1997, Titik Pandang Untuk Orde Baru, Pustaka Sinar Harapan, Jakarta, P. 342-347.
} 
people to live in prosperity is through corruption prevention which is the beginning of resolving various crises in Indonesia. ${ }^{14}$

This becomes important, because the criminal acts of corruption that occur within the scope of people's lives if left unchecked will hurt the justice of society. This is because corruption has taken people's rights against the law. Why not, the perpetrators of corruption have harmed the country's finances and taken people's money illegally and against the law.

This condition is clearly unfair to the people. The people are the true owners of state finances. Because state finances are obtained from taxes paid by the people and then used for full human development, such as education, health and poverty alleviation. For this reason, if corruption is rampant, the people will continue to be the victims. People's justice is not achieved and manifested by the emergence of corrupt behavior. Justice has very broad dimensions and dimensions in various fields. Especially in the field of law, justice certainly becomes a part of law enforcement based on the provisions of legislation. This will be intriguing if carried out by parties such as law enforcement.

The reforms which were inaugurated in 1998 by pressure groups, national figures, and other movements have forcefully demanded that this country be built and organized by upholding law and justice. The use of arbitrary and arbitrary power that is centered on the President and other state officials is prohibited and must be stopped immediately, and how the property of the earth is devoted to the interests of people's welfare in a fair and equitable manner. In short, the roll-out of the reform issue is essentially in favor of how complementary linkages and linkages are cohesive and consistent between the rule of law, a democratic country, and a welfare state that must be the foundation of the ideals of building a new Republic of Indonesia. ${ }^{15}$

According to W.A.M Luypen in his theory of justice that the formation of law needs to be guided by justice. Justice is the basis and critical norm in the law. This is absolutely necessary, if not, fair living together is not possible. ${ }^{16}$ In the case of corruption, justice can be seen in the context of upholding the law, especially criminal law. Criminal law is more specialized in the study of various kinds of crimes. Including corruption crimes that occur.

The use of criminal law to suppress crime is indeed debated, because criminal law is an ultimumremedium. In a sense, the enforcement of criminal law in the context of crime prevention is not the only hope. However, in this aspect of law enforcement, the meaning of Indonesia as a legal state is at stake in its success. ${ }^{17}$

W.P.J. Pompe stressed that the focus of criminal law in its current development was the public interest or the interests of the community. ${ }^{18}$ Therefore, the main key point in the enforcement of criminal acts of corruption is to create a commitment from law enforcement to work professionally and provide a search for intelligent evidence. Thus, disclosure of evidence is very easy to trace, because the relevant laws and regulations are sufficient. ${ }^{19}$

\footnotetext{
${ }^{14}$ Arya Maheka, 2006, Mengenali Dan Memberantas Korupsi, Komisi Pemberantasan Korupsi, Jakarta, p. 4.

${ }^{15}$ Butir-Butir Pemikiran Dalam Hukum: Memperingati 70 Tahun Prof. Dr. B. Arief Sidharta.,SH, Penyunting Sri Rahayu Oktoberina Dan Niken Savitri, 2008, PT. Refika Aditama, Bandung, p. 215.

${ }^{16}$ Satjipto Rahardjo, 2013, Teori Hukum Strategi Tertib Manusia Lintas Ruang Dan Generasi, Genta Publishing, Yogyakarta, p. 173.

${ }^{17}$ Muladi, 2002, Kapita Selekta Sistem Peradilan Pidana, Cetakan II Badan Penerbit Universitas Diponegoro, Semarang, p. 7.

${ }^{18}$ Bambang Poernomo, 1985, Asas-Asas Hukum Pidana, Ghalia Indonesia, Jakarta, p. 37.

${ }^{19}$ Syaiful Bakhri, 2012, Beban Pembuktian: Dalam Beberapa Praktik Peradilan, Gramata Publishing, Depok, p. 48.
} 
In cases of corruption, disclosure of this case can be proven by presenting witnesses and various other evidences. This is very seriously sought and the seriousness of law enforcers to prove that the alleged perpetrators of corruption are those who deserve to be punished.

Law has two main tasks, namely achieving legal certainty and achieving justice for all people. Among the many thoughts and concepts of justice, one concept of justice that is quite relevant is as conceptualized by Roscoe Pound. This legal sociology thinker says that justice is not merely a juridical issue, but a social problem which is in many ways highlighted by the sociology of law. ${ }^{20}$

In connection with the occurrence of criminal acts of corruption committed by corruptors, the corruptors have stolen money that should be used to prosper the people. Therefore they corruptors have hurt the sense of justice of the community. Corruption inhibits the progress of the nation, destroys democracy and afflicts the people. Corruption perpetrators enjoy the results of corruption without rights and deliberately enrich themselves. In this case the perpetrators enrich themselves by taking state money. Such corruption can be said as a crime that has a very extraordinary impact on the development of a whole person.

Frans Magnis Suseno explained that the practice of corruption in Indonesia had arrived at the most dangerous in the life of the nation and state. The state economy is always in a position that is not good for the journey of development in Indonesia, but in its journey then more than that is to endanger and damage the economy of the community. ${ }^{21}$

Based on the description above, we as a society must not allow corruption as a thriving culture. Corruption occurs systematically, structured and massive in various fields of life that should not be allowed to develop. In Pancasila and the 1945 Constitution corruption is not a culture for this country. Because it is not in line with the ideals of the struggle of the founding fathers who are nothing but for the welfare and prosperity of the people. Corruption has made the poor and miserable people. Corruption takes people's rights against the law. So the culture of corruption that injures this sense of justice must be ended immediately. If corruption becomes a culture for this country, this country will experience destruction.

\section{Judge's Consideration in Making a Free Decision Against Corruption Actors}

Law enforcement in corruption cases is quite paradoxical and is still far from a sense of justice in society. One of them is because of a lot of judges in Indonesia who had sentenced light perpetrators to corruption. ${ }^{22}$

A judge in the case of imposing a sentence on a defendant may not impose the criminal offense unless with at least two valid evidences, so that the judge obtains the conviction that a criminal act actually occurred and the accused is guilty of doing so (Article 183 of the Criminal Procedure Code). The legal evidence in question is: (a). Witness Information; (b). Information of Experts; (c). Letter; (d). Directions; (e). Information on Defendants or things that are generally known so that they do not need to be proven

\footnotetext{
${ }^{20}$ Umar Sholahudin, Hukum Dan Keadilan Masyarakat (Analisis Sosiologi Hukum Terhadap Kasus Hukum Masyarakat Miskin “Asyani” Di Kabupaten Situbondo), Dimensi, Jurnal Sosiologi Vol. 9, No. 1 Juni, 2016, p. 42.

${ }^{21}$ R. Diyatmiko Soemodihardjo, 2008,Mencegah dan Memberantas Korupsi, Mencermati Dinamikanya di Indonesia, Prestasi Pustaka Publisher, Jakarta, p. 3.

${ }_{22}$ Asep Syarifuddin Hidayat, Pendidikan Kampus Sebagai Media Penanaman Nilai - Nilai Antikorupsi Bagi Mahasiswa, SALAM; Jurnal Sosial \& Budaya Syar-i, FSH UIN Syarif Hidayatullah Jakarta, Vol. 6 No. 1, 2019, p. 45.
} 
(Article 184 KUHAP). The judge's decision must always be based on the case delegation letter which contains all the charges for the defendant's wrongdoing regarding criminal acts committed unlawfully.

The essence of the elements of criminal acts is that the principal is in the form of a behavior (effect) that is against the law, both formal and material. There is an unlawful element in this matter for the legislators who mentions "against the law" in its formulation and there are also those that are not mentioned "against the law" in the formulation, but all argue that going against the law is always a mistake. ${ }^{23}$

The existence of formal teachings against the law is not a problem because this is explicitly an element of an article, so to determine whether someone is doing something that is against the law or not, enough if the person sees whether the act fulfills all the elements contained in the formula offended or not. ${ }^{24}$

Unlawful acts in corruption also include unlawful acts in the formal sense and in the material sense, that is, even though the act is not regulated in legislation, but if the deed is considered despicable because it is not in accordance with the sense of justice or norms of social life in the community, the act can be punished (Explanation of article 2 paragraph (1) of the PTPK Law). In essence, the existence or absence of elements of illegal acts on corruption acts the same concept as violations of articles in the Criminal Code (KUHP)..$^{25}$

Sudarto said formal offenses were offenses whose formulas focused on prohibited acts. The offense has been completed by carrying out an action as stated in the offense formulation. From this understanding, it must be concluded that the existence of a criminal act of corruption or to prove a person or corporation, is sufficiently only proven by the fulfillment of the elements of a unlawful act that have not been formed. ${ }^{26}$

Unlawful elements in corruption cases are important and decisive for the existence of a criminal act of corruption that must be accounted for, both job responsibility and personal responsibility. The provisions of Article 2 paragraph (1) and Article 3 of the Law on Corruption Crime are formal offenses. This means that the existence of criminal acts of corruption is enough to fulfill the formulation of offenses, not with the emergence of consequences. ${ }^{27}$

The nature of opposing material law in a positive function is interpreted, but if the deed is considered disgraceful because it is not in accordance with a sense of justice or norms of justice or norms of social life, the act can be punished. The nature of opposing the material law in the negative sense is intended even though the act has fulfilled the element of offense, but the action does not conflict with the sense of justice of the community, then the act cannot be punished. ${ }^{28}$ An act of corruption can be punished not only based on the provisions of written criminal law but also on the law not written. This certainly results in criminal law experts having differences regarding the relevance of the teachings of the nature against material law in this positive function. ${ }^{29}$

\footnotetext{
${ }^{23}$ Ibid, p.73.

${ }^{24}$ Juventhy M Siahaan, 2016, Perbuatan Melawan Hukum, Lembaga Bantuan Hukum: Advokasi Masyarakat Indonesia, Edisi Juni.

${ }_{25}^{25}$ Abdul RaisAsmar, 2012, Perbuatan Melawan Hukum Dalam Tindak Pidana Korupsi, Negara Hukum, 6 Maret.

${ }^{26}$ Sudarto, 2009, Hukum Pidana I (EdisiRevisi), Yayasan Sudarto, Semarang, p. 96.

${ }^{27}$ Mas Toha Wiku Aji, Umi Rozah Aditya, Purwoto, Analisis Sifat Melawan Hukum Dalam Tindak Pidana Korupsi (Studi Putusan No:174/Pid.B/2009/Pn.Pwt), Diponegoro Law Journal Volume 6, Nomor 2, 2017, p.7.

${ }^{28}$ LilikMulyadi, 2012, Bunga Rampai Hukum Pidana Umum dan Khusus, Alumni, Bandung, p. 23.

${ }^{29}$ Seno Wibowo, Ratna Nurhaya, Perbedaan Pandangan Ajaran Sifat Melawan Hukum Materiil Tindak Pidana Korupsi, PADJADJARAN Jurnal Ilmu Hukum, Volume 2 Nomor 2, 2015, p. 355.
} 
The problem of corruption is very multi-complex caused by various multi-dimensional factors, so handling the problem of corruption includes prosecution of someone suspected of committing corruption if possible, should be targeted not only for the sake of legal justice, but also in terms of the economy including state finances. ${ }^{30}$

But the main thing of all is that the judges in making decisions on various crimes must be as fair as possible. The judge is the spearhead of the rule of law in this country. The judge is an independent power and free from any influence.

The judge is the spearhead of justice for society. However, on the other hand the judge is also burdened with professional responsibility, meaning that the judge cannot be arbitrary in carrying out his duties, the judge has responsibilities, both morally, lawfully, and technically in his profession. Judges have a very central role in law enforcement. ${ }^{31}$ Judges have the authority to decide cases, who is right and who is wrong. Judges must not take sides, unlike prosecutors who must side with the interests of the state and try to prove the existence of a mistake (reason for upholding the law). ${ }^{32}$ Judges must uphold their noble performance and integrity and must adhere to the prescribed code of ethics and code of conduct of judges. Although many temptations are faced, judges should still be on a straight path, because the judge is one of the pillars of law enforcement. ${ }^{33}$

Judges must have integrity and personality that is impeccable, honest, fair, professional. Professionals and experienced in the field of law are intellectual requirements that must be met. But there are other more basic requirements, namely high personality integrity or honesty (istiqomah), if attitudes, actions, and activities in carrying out tasks and daily life are based on worship. ${ }^{34}$ Once the importance of the role of the judge through its decision, it becomes important that the judge's decision can reflect a sense of justice for the community in every corruption case.

Regarding the judge's decision or "court decision" is an important aspect and is needed to resolve a criminal case. Thus, it can be further concluded that the "judge's decision" on the one hand is useful for the defendant obtaining legal certainty (rechtszekerheids) about his "status" and at the same time preparing the next step against the judge's decision. Whereas on the other hand, if examined through the essential vision that hears the case, the judge's decision is the "crown" and "peak" reflecting the values of justice, ultimate truth, human rights, mastery of the law or facts in an established, capable, and factual, as well as visualization ethics, mentality, and morality of the judge concerned. ${ }^{35}$

LedenMarpaung gives an understanding of the judge's decision is the result or conclusion of something that has been considered and assessed as carefully as possible in the form of written or oral. ${ }^{36}$ According to the provisions of the criminal law in imposing a sentence on the defendant not based on the weight but the effectiveness of

\footnotetext{
${ }^{30}$ Wahyu Wiriadinata, Korupsi Dalam Pencurian Aliran Listrik Dalam Pasal 2 Ayat (1) Undang-Undang Nomor 31 Tahun 1999 Tentang Pemberantasan Tindak Pidana Korupsi, Jurnal Ilmiah Kebijakan Hukum, Kementerian Hukum Dan Ham Ri, Volume 8 Nomor 3, Oktober, 2014, p. 320.

${ }^{31}$ Prianter Jaya Hairi, Kebijakan Kriminalisasi TerhadapTindakan Hakim Dalam RancanganUndang-Undang Tentang Mahkamah Agung, Jurnal Ilmiah Hukum Negara Hukum: Membangun Hukum Untuk Keadilan Dan Kesejahteraan, Vol. 5 No. 1, Juni, 2014, p. 50.

${ }^{32}$ A. Muliadi, Peran Politik Hukum Dalam Penegakan Hukum Yang Berkeadilan, Adil Jurnal Hukum, Fakultas Hukum Universitas Yarsi, Vol. 2 No. 2, Agustus, 2011, p.160.

${ }_{33}$ ArristaTrimaya, Peranan Hakim Sebagai Agent Of Change Dalam Melakukan Reformasi Peradilan Tata Usaha Negara, Jurnal Perundang-Undangan Prodigy, Volume 1 No. 1, November, 2013, p. 131.

${ }_{34}$ Nurhadiantomo, Kekuasaan Kehakiman Dan Pandangan Hukum Progresif: Hakim Dan Rasa Keadilan Masyarakat, Jurnal Pranata Hukum, Vol. 1, No 1, 2006, P. 1.

${ }^{35}$ LilikMulyadi, 2007, Tindak Pidana Korupsi Di Indonesia Normatif, Teoretis, Praktik, Dan Masalahnya, Alumni, Bandung, p. 119.

${ }^{36}$ Leden Marpaung, 1992, Proses Penanganan Perkara Pidana. Sinar Grafika, Jakarta, p. 76.
} 
the decision to the defendant. If the defendant is sentenced to low or while after serving the sentence the ex-convict will no longer commit an act or is aware of the wrongdoing done, then the judge's decision is effective that the former convict did not commit a crime again and has lived the right life in accordance with expectations society. ${ }^{37}$

In imposing punishments based on their effectiveness in line with the principles adopted by the Penitentiary (LP) that convicts are called fostered members are no longer called prisoners who treat prisoners as human beings or humanize human beings and provide work training while serving sentences for working capital after completion punishment. $^{38}$

Court decisions are the output of a judicial process in a court session which includes the process of examining witnesses, examining defendants, and examining evidence. When the process of proof is declared completed by the judge, the time comes for the judge to make a decision. ${ }^{39}$ The Judge's decision is essentially: 1 . Decisions made in court proceedings that are open to the public 2. Decisions are imposed by the judge after going through the process and procedural criminal procedure in general. ${ }^{40}$

Implementively, there are several judges' decisions which impose punishment on the perpetrators of corruption under the threat limit stipulated in the special minimum criminal provisions Act on the Eradication of Corruption Crime (UUPTPK). Judges who in their decisions break the criminal provisions of this special Mininum course have legal reasoning that can be accounted for.Even though this will lead to conflict between the dimensions of legal certainty and the dimension of legal justice. ${ }^{4}$

In a corruption case, according to data compiled by Indonesia Corruption Wacht (ICW), the first semester of 2016 corruption verdict showed that out of a total of 384 defendants, 275 or 71.6 percent received mild sentences, namely one to four years in prison. While 46 defendants were acquitted, 37 defendants were sentenced to moderate, 7 were severely sentenced, and 19 others were not identified. ICW concludes the verdict against the perpetrators of corruption, has not caused a deterrent effect. It also does not support the spirit of corruption eradication which seeks to punish corruptors with the most severe penalties. ${ }^{42}$

Meanwhile, in 2017 in ICW's record, there were 315 cases of corruption cases with 348 defendants at the beginning of the first semester. The verdicts handed down on the case were varied but ICW was judged to be mostly light. Of the 348 defendants, 22 were acquitted, 262 were sent off 0-4 years in prison, 41 were sentenced to 4-10 years in prison, 3 were sentenced to 10 years in prison, and 20 were not identified. From that number, 262 corruptors were sentenced to $0-4$ years in prison which were included in the mild category. ${ }^{43}$

The judge in deciding corruption cases is certainly based on the indictment submitted by the public prosecutor. The use of articles in the corruption case charges also affected the magnitude of the sentence imposed on the accused. This is because each article in the Corruption Law has a maximum formal and criminal minimum formal crime. In

\footnotetext{
${ }^{37}$ Monang Siahaan, 2015, KPK dan Polri Bersatulah Memberantas Korupsi, PT. Elex Media Komputindo, Jakarta, p.6.

${ }^{38}$ Ibid, p.7.

${ }^{39}$ H. Rusli Muhammad, 2007, Hukum Acara Pidana Kontemporer, Citra Aditya Bakti, bandung, p. 199.

${ }^{40}$ Susanti Ante, Pembuktian Dan Putusan Pengadilan Dalam Acara Pidana, Jurnal Lex Crimen Vol. Ii/No. 2/April- Juni, 2013, p.103.

${ }^{41}$ Suwito, Putusan Pengadilan Tindak Pidana Korupsi yang Menerobos Ketentuan Pidana Minimum Khusus sebagai Bentuk Penemuan Hukum oleh Hakim, Khairun Law Journal, Vol. 1 Issue 1 September, 2017, p.52.

${ }^{42}$ Beritagar, 2016, Remisi Koruptor Di Antara Hak Dan Rasa Keadilan, Kamis, 18 Agustus.

${ }^{43}$ Akhmad Mustaqim, 2017, ICW: Hingga Pertengahan 2017, Ada 22 Vonis Bebas Kasus Korupsi, Detiknews, 13 Agustus.
} 
Article 2 paragraph (1) of the Corruption Law, for example, it is stated that imprisonment that can be imposed on perpetrators of corruption is 4 (four) years and a maximum of 20 years. In practice, both prosecutors and judges will weigh based on the findings and evidence obtained in the process of investigation and construction of the existing indictments, the length of time of imprisonment that can be prosecuted or imposed on the accused. The imposition of a verdict is free in a corruption case, because in the facts at the trial the elements of criminal corruption charged against the accused were not fulfilled. The lightness of the verdicts imposed by the judges certainly does not deter corruptors, moreover the convicts of corruption cases then easily accept remissions and parole from the Ministry of Law and Human Rights of Manusa (HAM). In the end, the entrapment of perpetrators of corruption is only a discourse among law enforcement officials.

The cause of the free verdict in corruption cases is the difference in perceptions between prosecutors and judges regarding both the application of the law and the assessment of the facts revealed in the trial, the mistake or inaccuracy of the public prosecutor in applying the indictment including juridical discussion in the letter of claim filed by the public prosecutor is less than optimal so as to create a gap for the judge to declare that the public prosecutor cannot prove his charges while the obstacles faced in prosecuting corruption cases in addition to difficult proof, are also inseparable from the characteristics of corruption, both juridical and non-juridical constraints, for example : there is intervention from certain elements or officials of the government / state who want to free the defendant from responsibility, either by using power or authority of office or in return for money or with family. ${ }^{4}$

The lightness of the judge's decision in handling corruption cases was also followed by the performance of the judges in carrying out law enforcement duties. There are also judges who are trapped in a vortex of corruption. As a result, it can affect the decision. A mild judge's decision to even acquit the accused of corruption is certainly very unfortunate. Because this will hurt the feelings of the people, who should enjoy money corrupted by corruptors. For this reason, the judge's decision is an important factor in determining efforts to eradicate corruption.

Judges' consideration in making decisions according to Rusli Muhammad can be divided into two categories, namely: ${ }^{45}$ First, juridical considerations. Juridical considerations are judges' judgments based on juridical facts revealed in the trial and by the Law stipulated as matters that must be included in the verdict. The said things include: a. Indictment of the public prosecutor $b$. Information from the defendant c. Witness information $d$. Evidence Articles in the Criminal Law regulations. Second, considerations that are nonjuridical. Considerations that are non-juridical, namely, among others: a. Defendant's background. The background of the defendant's actions is any situation that causes a desire and a strong urge in the defendant to commit a criminal offense. $b$. As a result of the defendant's actions The criminal acts committed by the defendant must have brought casualties or losses to the other party. Even the consequences of the actions of the defendants from the crimes committed can also adversely affect the public, at least their security and tranquility are always threatened. c. The defendant's condition The

\footnotetext{
${ }^{44}$ Olan Laurance Hasiholan Pasaribu, Iman Jauhari, Elvi Zahara Lubis, Kajian Yuridis Terhadap Putusan Bebas Tindak Pidana Korupsi, (StudiKasus Pada Pengadilan Negeri Medan), Mercatoria, Vol. 1 No. 2 Tahun, 2008, p. 136.

${ }^{45}$ Rusli Muhammad, 2010, Hukum Acara Pidana Kontemporer, Citra Aditya Bakti, Bandung, p. 212.
} 
definition of the defendant's condition is the physical and psychological condition of the defendant before committing a crime, including the social status inherent in the defendant. The intended physical state is age and level of maturity, while the psychic state is intended to be related to feelings that can be in the form of pressure from others, the mind is in chaos, anger and others $d$. The religion of the accused The attachment of the judges to religious teachings is not enough to simply put the word "Godhead" on the head of the verdict, but must be a measure of the assessment of each act both the actions of the judges themselves and especially the actions of the evil makers.

Judges as places where justice seekers complain and resolve their problems, in enforcing the law through their verdicts, the judges as one component of law enforcement must provide the fairest decisions based on a sense of community justice. It is not easy for judges to implement this, because judges must also be guided by laws and regulations, thus between justice and legal certainty intersect. ${ }^{46}$

Judges' decisions or "court decisions" are important aspects and are needed to settle criminal cases. Thus, it can be further concluded that the "judge's decision" on the one hand is useful for the defendant obtaining legal certainty (rechtszekerheids) about his "status" and at the same time preparing the next step against the judge's decision. Whereas, on the other hand, if examined through the essential vision that hears the case, the judge's decision is the "crown" and "peak" reflecting the values of justice, essential truth, human rights, mastery of the law or facts in an established, capable, and factual fact, and visualization of ethics, mentality, and morality from the judge concerned. ${ }^{47}$

The value of justice of the judge's decision on the case of corruption is essentially to prevent the occurrence of unbalanced or impartial treatment, but in fact it is less realized so that the judge's decision is felt by justice seekers as a decision that does not contain justice values, but merely has the tendency to punish and violate the rights of criminal offenders. Judges' decisions on corruption cases that reflect the value of justice are determined by criteria, if the judge's decision is carried out in a professional manner, and supported by the judge's high moral integrity, then the judge's decision is considered to contain justice values. ${ }^{48}$

In the future in handling corruption cases, judges as law enforcers and justice are prosecuted professionals and have high moral integrity and independence in examining and deciding cases. Judges must not be affected by forces that can ultimately influence their decisions. This is important, because in the hands of judges all the inspection processes and the end of the judiciary can be realized. The public does not want to hear anymore that in handling cases of corruption, the judge decided that the case was no longer with a mild verdict that tended to ignore the sense of justice. Decisions of judges who ignore the values of justice must not be felt by the public and seekers of justice in the future.

\section{CONCLUSION}

${ }^{46}$ Carto Nuryanto, Penegakan Hukum Oleh Hakim Dalam Putusannya Antara Kepastian Hukum Dan Keadilan,Jurnal Hukum Khaira Ummah, Vol. 13. No. 1 Maret, 2018, p. 74.

${ }^{47}$ Lilik Mulyadi, Op cit, p. 119.

${ }^{48}$ H. MuslihinRais, 2017, Nilai Keadilan Putusan Hakim Pada Perkara Tindak Pidana Korupsi, Jurnal Aldaulah, Vol. 6 / No. 1 / Juni, p. 7143.

12 Jurnal IUS Kajian Hukum dan Keadilan 
Please follow conclusion format in Jurnal IUS That corruption can injure public justice is because the perpetrators of corruption have taken people's rights against the law, the perpetrators have enriched themselves by taking state money, corruption perpetrators have hampered the nation's progress, corruption perpetrators have undermined democracy and caused misery to the people. Such corruption can be said as a crime that has a very extraordinary impact on the development of a whole person. In connection with the occurrence of criminal acts of corruption committed by corruptors, the corruptors have stolen money that should be used to prosper the people. Therefore they corruptors have hurt the sense of justice of the community.

Regarding the number of judges' decisions that are light and even free of corruption, it is certainly very unfortunate that the judge's verdict in corruption cases has implications for the sense of justice of the community, this is because the judge's decision is the crown and the ultimate reflection of values of justice, essential truth and human rights. The judge is the spearhead of justice for society. Judges must not be affected by forces that can ultimately influence their decisions. This is important, because in the hands of judges all the inspection processes and the end of the judiciary can be realized. The public does not want to hear anymore that in handling corruption cases, judges decide cases by ignoring a sense of justice.

\section{BIBLIOGRAPHY}

\section{Books}

Amir Syamsuddin, (2008), Integritas Penegak Hukum, Hakim, Jaksa, Polisi, Dan Pengacara, Gramedia, Jakarta.

Alfitra, (2014), Modus Operandi Pidana Khusus Diluar KUHP, Raih Asa Sukses, Depok.

A.Hamzah, (2005), Pemberantasan Korupsi Melalui Hukum Pidana Nasional Dan Internasional, Raja Grafindo Persada, Jakarta.

Albert Hasibuan, (1997), Titik Pandang Untuk Orde Baru, Pustaka Sinar Harapan, Jakarta.

Arya Maheka, (2006), Mengenali Dan Memberantas Korupsi, Komisi Pemberantasan Korupsi, Jakarta.

Bambang Poernomo, (1985), Asas-Asas Hukum Pidana, Ghalia Indonesia, Jakarta.

Butir-Butir Pemikiran Dalam Hukum: Memperingati 70 Tahun Prof. Dr. B. Arief Sidharta.,SH, Penyunting Sri Rahayu Oktoberina Dan Niken Savitri, (2008), Pt. Refika Aditama, Bandung.

Endang Jumali, (2016), Rekonstruksi Sanksi Hukum Pidana Korupsi Di Indonesia, Kritik Nazharyyah Al-Ta'zir, Terhadap Undang-UndangNomor 20 Tahun 2001 Tentang Pemberantasan Tindak Pidana Korupsi, PT. Saadah Pustaka Mandiri, Jakarta.

H. Elwi Danil, (2011), Korupsi: Konsep, Tindak Pidana, Dan Pemberantasannya, Raja Grafindo Persada, Jakarta.

H. Rusli Muhammad, (2007), Hukum Acara Pidana Kontemporer, Citra Aditya Bakti, Bandung.

Lilik Mulyadi, (2012), Bunga Rampai Hukum Pidana Umum dan Khusus, Alumni, 
Jurnal IUS Kajian Hukum dan Keadil an | Vol VIII | Nomor 1 | April 2020 | hlm, 14 16

Bandung.

, (2007), Tindak Pidana Korupsi Di Indonesia Normatif, Teoretis, Praktik, Dan Masalahnya, Alumni, Bandung.

Leden Marpaung, (1992), Proses Penanganan Perkara Pidana.Sinar Grafika, Jakarta.

M. Dede Ridwan Dan M. Muhadjirin, (2003), Membangun Konsensus Pemikiran Dan

Praktik Politik Akbar Tanjung, Pustaka Sinar Harapan, Jakarta.

Monang Siahaan, (2015), KPK dan Polri Bersatulah Memberantas Korupsi, PT. Elex Media Komputindo, Jakarta.

Muladi, (2002), Kapita Selekta Sistem Peradilan Pidana, Cetakan II, Badan Penerbit Universitas Diponegoro, Semarang.

Rusli Muhammad, (2010), Hukum Acara Pidana Kontemporer, Citra Aditya Bakti, Bandung.

R. Diyatmiko Soemodihardjo, (2008), Mencegah dan Memberantas Korupsi, Mencermati Dinamikanya di Indonesia, Prestasi Pustaka Publisher, Jakarta.

Satjipto Rahardjo, (2013), Teori Hukum Strategi Tertib Manusia Lintas Ruang Dan Generasi, Genta Publishing, Yogyakarta.

Soerjono Soekanto dan Sri Mamudji, (2001), Penelitian Hukum Normatif, Raja Grafindo, Jakarta.

Syaiful Bakhri, (2009), Pidana Denda Dan Korupsi, Total Media, Yogyakarta.

(2012), Beban Pembuktian: Dalam Beberapa Praktik Peradilan, Gramata Publishing, Depok.

Sudarto, , 2009. Hukum Pidana I (EdisiRevisi), Yayasan Sudarto, Semarang.

TB Roni Nitibaskara, (2006). Tegakkan Hukum Gunakan Hukum, Kompas, Jakarta.

\section{Law and Regulation}

Undang-UndangNomor 31 tahun 1999 tentang Pemberantasan Tindak Pidana Korupsi Undang-UndangNomor 20 tahun 2001 tentang Pemberantasan Tindak Pidana Korupsi Undang-UndangNomor 1 tahun 1946 tentang Kitab Undang-Undang Hukum Pidana

Undang-UndangNomor 8 tahun 1981 tentang Kitab Undang-Undang Hukum Acara Pidana

\section{Journal/Mass Media / Papers / Dictionaries}

A. Muliadi, (2011), Peran Politik Hukum Dalam Penegakan Hukum Yang Berkeadilan, Adil Jurnal Hukum, Fakultas Hukum Universitas Yarsi, Vol. 2 No. 2, Agustus.

Arrista Trimaya, (2013), Peranan Hakim Sebagai Agent Of Change Dalam Melakukan Reformasi Peradilan Tata Usaha Negara, Jurnal Perundang-Undangan Prodigy, Volume 1 No. 1, November.

Akhmad Mustaqim, (2017), Icw: Hingga Pertengahan 2017, Ada 22 Vonis Bebas Kasus Korupsi, Detiknews,13 Agustus.

Abdul Rais Asmar, (2012), Perbuatan MelawanHukum Dalam Tindak Pidana Korupsi, Majalah NegaraHukum, 6 Maret. 
Asep Syarifuddin Hidayat, (2019), Pendidikan Kampus Sebagai Media Penanaman Nilai-Nilai Antikorupsi Bagi Mahasiswa, SALAM; Jurnal Sosial \& Budaya Syar-i, FSH UIN Syarif Hidayatullah Jakarta, Vol. 6 No. 1.

Beritagar, (2016), Remisi Koruptor Di Antara Hak Dan Rasa Keadilan, Kamis, 18 Agustus.

Carto Nuryanto, (2018), Penegakan Hukum Oleh Hakim Dalam Putusannya Antara Kepastian Hukum Dan Keadilan, Jurnal Hukum Khaira Ummah, Vol. 13. No. 1 Maret.

Departemen Pendidikan dan Kebudayaan RI, (1995), Kamus Besar Bahasa Indonesia ,(Jakarta: Balai Pustaka.

Harkristuti Harkrisnowo, (2012), "Korupsi, Konspirasi dan Keadilan di Indonesia", Jurnal Dictum LeIP, Edisi I, Jakarta, Lentera Hati.

H. Muslihin Rais, (2017), Nilai Keadilan Putusan Hakim Pada Perkara Tindak Pidana Korupsi, Jurnal Aldaulah, Vol. 6 / No. 1 / Juni.

Juventhy M Siahaan, (2016), Perbuatan Melawan Hukum, Lembaga Bantuan Hukum: Majalah Advokasi Masyarakat Indonesia, Edisi Juni.

Mas TohaWiku Aji, Umi Rozah Aditya, Purwoto, (2017), Analisis Sifat Melawan Hukum Dalam Tindak Pidana Korupsi (Studi Putusan No:174/Pid.B/2009/ Pn.Pwt), DIPONEGORO LAW JOURNAL, Volume 6, Nomor 2.

M. Syamsa Ardisasmita, (2006), Definisi Korupsi Menurut Perspektif Hukum Dan E-Announcement Untuk Tata Kelola Pemerintahan Yang Lebih Terbuka, Transparan Dan Akuntabel, Disampaikan Dalam Seminar Nasional Upaya Perbaikan Sistem Penyelenggaraan Pengadaan Barang/Jasa Pemerintah Jakarta, 23 Agustus.

Nurhadiantomo, (2006), Kekuasaan Kehakiman Dan Pandangan Hukum Progresif: Hakim Dan Rasa Keadilan Masyarakat, Jurnal Pranata Hukum, Vol. 1, No 1.

Olan Laurance Hasiholan Pasaribu, Iman Jauhari, Elvi Zahara Lubis, (2008), Kajian Yuridis Terhadap Putusan Bebas Tindak Pidana Korupsi, (Studi Kasus Pada Pengadilan Negeri Medan), Jurnal Mercatoria, Vol. 1 No. 2.

Prianter Jaya Hairi, (2014), Kebijakan Kriminalisasi Terhadap Tindakan Hakim Dalam Rancangan Undang-Undang Tentang Mahkamah Agung, Jurnal Mmiah Hukum Negara Hukum: Membangun Hukum Untuk Keadilan Dan Kesejahteraan, Vol. 5 No. 1, Juni.

Susanti Ante, (2013), Pembuktian Dan Putusan Pengadilan Dalam Acara Pidana, Jurnal Lex Crimen, Vol. II/No. 2/April-Juni.

Suwito, (2017), Putusan Pengadilan Tindak Pidana Korupsi yang Menerobos Ketentuan Pidana Minimum Khusus sebagai Bentuk Penemuan Hukum oleh Hakim, Khairun Law Journal, Vol. 1 Issue 1 September.

Seno Wibowo, Ratna Nurhaya, (2015), Perbedaan Pandangan Ajaran Sifat Melawan Hukum Materiil Tindak Pidana Korupsi, PADJADJARAN Jurnal Ilmu Hukum, Volume 2 Nomor 2.

Wahyu Wiriadinata, (2014), Korupsi Dalam Pencurian Aliran Listrik Dalam Pasal 2 
Ayat (1) Undang-Undang Nomor 31 Tahun 1999 Tentang Pemberantasan Tindak Pidana Korupsi, Jurnal Mmiah Kebijakan Hukum, Kementerian Hukum Dan Ham RI, Volume 8 Nomor 3, Oktober.

Umar Sholahudin, (2016), Hukum Dan Keadilan Masyarakat (Analisis Sosiologi Hukum Terhadap Kasus Hukum Masyarakat Miskin “Asyani” Di Kabupaten Situbondo), Dimensi, Jurnal Sosiologi, Vol. 9/No. 1 Juni. 